\title{
Die Landgnterordnung
}

\section{Kaiser Karls des Grolsen.}

(Capitulare de villis rel curtis imperii.)

\author{
Text-Ausgabe \\ mit Einleitung und Anmerkungen
}

herausgegeben

von

\section{Dr. Karl Gareis,}

Geh. Justizrath, ord. Professor der Bechte in Konigsberg i. Pr.

\section{BERLIN SW ${ }^{48}$}

Wilhelmstrafse 119/120.

J. Guttentag, Verlagsbuchhandlung. 1895. 
